\title{
THE EFFECTIVENESS OF FINISHING SCHOOL PROGRAMMES FROM THE PERSPECTIVES OF GRADUATES AND EMPLOYERS
}

\author{
${ }^{1}$ Jamal Ali, ${ }^{2}$ Lim Hock Eam, ${ }^{3}$ Russayani Ismail, \\ ${ }^{4}$ Fauziah Abdul Rahim, ${ }^{5}$ Filzah Md Isa \& ${ }^{6}$ Ismi Arif Ismail \\ 1,2,3,5 School of Business Management,Universiti Utara Malaysia \\ ${ }^{4}$ School of Education and Modern Languages \\ Universiti Utara Malaysia \\ ${ }^{6}$ Faculty of Educational Studies \\ Universiti Putra Malaysia
}

${ }^{1}$ Corresponding author: jamalali@uum.edu.my

\begin{abstract}
Purpose - This study examined the effectiveness of Finishing School programmes in enhancing the employability of graduates from institutions of higher learning. The perceptions of the graduates and employers towards the effectiveness of the programmes were analyzed. The effectiveness of Finishing School programmes evaluated through a graduate marketability outcome study and the expectations of employers with regard to the type of soft skills of graduates most needed by industries were also examined.
\end{abstract}

Methodology - Data for this study were obtained through a survey questionnaire administered to graduates and focus group interviews with selected employers. The primary data involved a large sample $(n=1092)$ of graduates from public universities and also 31 selected employers from various industries. The data were analysed using descriptive statistics, Chi-square tests, and a multinomial logit model. Due to the unavailability of a population frame, the data were collected using a convenient sampling design.

Findings - Graduates had a positive perception of the effectiveness of Finishing School programmes. However, in terms of the marketability outcome, Finishing school programmes currently 
being offered were seen as ineffective. Interviews with officers at the management level from various companies showed that the local graduates were lacking in certain types of soft skills, particularly in English communication skills, compared with their counterparts who graduated from higher education institutions overseas. Employers listed three skills as critical for graduates to have, namely, problem solving skills, information management (exposure to general knowledge, current issues and ICT) and English communication.

Significance-Most of the soft skills which employers have identified as important in enhancing graduates' employability have long been emphasized by the local higher learning institutions through their Finishing School programmes. Hence, it was concluded that the existing Finishing School programmes are indeed moving in the right direction in achieving its desired objectives. However, there is still room for improvement. This is especially so in relation to its implementation as the empirical evidence seems to suggest that current Finishing School programmes are not effective in terms of graduate marketability outcome.

Keywords: Finishing school programmes, graduates' employability, soft skills, higher education institutions.

\section{INTRODUCTION}

As the world faces greater global economic challenges that in turn will affect the local situation, graduate employability, which is the ability of graduates to gain employment that commensurate with their qualifications, has become the central focus of the Higher Education Sector in the Ministry of Education (HESME) (referred to as the Ministry of Higher Education, Malaysia (MoHE) prior to 2013). Several factors have been identified as the possible causes for the increase in the unemployment rate among university graduates in Malaysia. One of the principal causes of unemployment among the graduates is the skill mismatch between the requirements of the industry and the knowledge possessed by graduates. Such a mismatch may be partly due to changes in the economic structure and technological advancement, which have made the current labor market more competitive and volatile. As a result, graduates face difficulties in getting jobs because they are not ready for industry. 
Besides, depending on the nature of vacancies, firms often require people with some work experience, as was highlighted by Mlatsheni (2005). Work experience is an important factor that influences employability at all levels. Shamsuddin (2009) revealed that most firms, due to insufficient funds for training, expect fresh graduates to be able to start and contribute to the firm immediately as soon as they enter the job market.

On the other hand, Feng (2008) stated that part of the high unemployment rate for graduates could be attributed to a country's higher education expansion policy, whereby there were many incentives to establish new colleges and universities so as to be able to accept as many high school graduates as possible. Greater enrolment in higher education institutions might have a detrimental effect on the quality of education provided to the students which then led to the possibility of unemployment. This detrimental effect was further worsened by the decrease in demand for graduates due to the economic recession after the 1997 financial crisis (Lim, Rich \& Harris, 2008).

A survey conducted on 3300 human resource officers and bosses by JobStreet.com, a Malaysian employment agency, revealed several possible factors relating to graduate unemployment. These included the weak command of English (56 percent), bad social etiquette (36 percent), graduates demanding too much pay (32 percent), irrelevant degrees (30 percent), choosy job seekers among graduates (23 percent) and no vacancies (14 percent) (Gurvinder \& Sharan, 2008). Graduates' weak command of English and bad social etiquette were the top reasons for their being unemployed. These findings provide evidence that Malaysian graduates are unemployed not because they are unintelligent but rather because most of them are lacking in certain types of soft-skills.

In this regard, the Ministry of HigherEducation(MoHE) had embarked on several programmes and initiatives to mitigate the problems of deficiencies in soft skills among fresh graduates. Initiatives by the MoHE included the introduction of basic entrepreneurship modules and soft-skill modules to embed communication skills, leadership and team building as well as reporting skills into the student's curriculum. Internship or Industrial Training Programmes and collaborative programmes with the relevant industries were further 
enhanced and structured, as these types of programmes could provide added value to students' hands-on experience which could then be transferred to the actual work setting.

The MoHE also encouraged all public higher learning institutions to establish Finishing School programmes so as to meet the requirements of the industries. The development of the Finishing School programmes in local higher learning institutions was aimed at training and preparing final semester students as well as unemployed graduates with industry-specific knowledge, skills and competencies in order to facilitate and improve their employability. Despites enormous effort initiated to ensure the success of the programme, there were not many studies done to evaluate the effectiveness of the programmes, particularly relating to the issue of graduate employability. Thus, this study attempts to examine the extent to which the Finishing School programmes conducted by various local higher learning institutions have really helped to enhance graduate employability.

\section{PROBLEM STATEMENT}

The global economic recession in combination with an expansion in higher education, has resulted in an excessive number of college graduates. This in turn has led to a high graduate unemployment rate and a competitive labor market. Besides having good academic achievements, graduates also need to have a strong combination of soft skills, such as communication skills, teamwork, public speaking and interview skills. Understanding that many employers not only make academic achievement the primary criterion for selection, the MoHE has recommended that all local higher learning institutions conduct Finishing School Programmes and offer courses in soft skills for their graduates to enhance their chances of being employed. Various steps were taken by local higher learning institutions to conduct Finishing School programmes as required by the ministry. A lot of effort was made by local higher learning institutions in identifying the essential skills, modules and approaches that were to be part of the critical input for the Finishing School programme. This was necessary to ensure that their graduates were well equipped with the right soft skills demanded by the various industrial sectors. 
Despite all the actions and efforts taken by the higher learning institutions to enhance graduate employability, several questions arose; First, to what extent have Finishing School programmes implemented by local higher learning institutions effectively improved graduates' soft skills? Second, how well have the Finishing School programmes organised by local higher learning institution succeeded in enhancing the graduate employability? Third, are the soft skills offered in the Finishing School programmes aligned with employer requirements?

\section{OBJECTIVES OF THE STUDY}

The general objective of this study was to measure the effectiveness of the Finishing School programmes in local higher learning institutions in enhancing graduate employability. The primary aim of the study was to evaluate the effectiveness of soft skills taught in the programme in assisting the graduates to be more competitive in the labour market, either locally or internationally. Whereas the specific objectives of this research were:

1. To determine the perception of the graduates in terms of the effectiveness of Finishing School programmes in improving their soft skills.

2. To estimate the effectiveness of Finishing School programmes on graduate marketability outcomes.

3. To determine employer perceptions and expectations of the soft skills possessed by current graduates.

\section{LITERATURE REVIEW}

Studies have demonstrated that the macroeconomic environment of a country may affect the ability of university graduates to find employment. Specifically, a high unemployment situation prolongs the time needed to find a job, whereas low unemployment makes that time shorter (Skimming, 2007). Currently, the number of job vacancies is decreasing, especially in the public sector, which may add to undergraduates' concerns about their future employment. At the same time, higher education expansion has resulted in an excessive number of university graduates, which in turn has 
led to an increase demand for jobs. Due to these compounding factors, naturally university graduates have accepted jobs that do not commensurate with the training they have received, leading to so-called "over-education" and "crowding-out" problems (Mason, William \& Crammer, 2006; Hillage, 1998). Accepting traditionally non-graduate occupations implies that university graduates are lowering their job expectations and their rate of return for the higher education degree that they have obtained. Research suggests that universities should look at the competencies provided by higher education institutions and the skills demanded by industries in the job market (Tracker \& Yost, 2002). At the same time, universities should provide graduates with knowledge and soft skills such as communication skills, leadership skills and teamwork skills in order to help lower the graduate unemployment rate. Student learning can be measured not only in terms of how well they can achieve the learning objectives or outcomes, but also in terms of the learning process that they experienced (Umar \& Ahmad, 2010). Brown and Hesketh (2004) pointed out that as more people were able to obtain higher education degrees, graduates should add value to their primary academic credentials to distinguish themselves from others with similar degrees in a competitive labor market. From employers' perspectives, 'employability' seems to refer to 'work readiness,' that is, possession of the skills, knowledge, attitudes and commercial understanding enabling new graduates to make productive contributions to organizational objectives soon after starting employment (Mason, Williams \& Cranmer, 2006).

Chung and Yet (2009) investigated undergraduates' core competencies and ability to meet the requirements set by employers and analysed the effectiveness of personal qualities and employability skills development in a private university in Malaysia. A questionnaire survey, mean score comparison, and independent sample t-test were used to capture the perception differential between 30 employers and 600 undergraduates from a local private university on the importance of employability skills. The results showed that the undergraduates were all highly competent in aspects of their personal qualities and certain skills. However, for skills such as critical thinking, planning, problem solving, oral communication, decision making, and negotiating, there was a slightly higher level of mismatch between employer and undergraduate perception on their importance and development in the university. Gurvinder and 
Sharan (2008) also studied the perceptions of employers concerning the employability skills needed in the job market and graduates' perception of the employability skills that they currently possessed. The results of their study revealed that employers preferred to hire graduates from public universities. Moreover, graduates and employers agreed about the importance of employability skills. Employer status also influenced the expectation of the graduates; the higher the job position of the employer within the organization, the higher the expectations.

Manishankar (2009) found that communication skills, personality traits, self-discipline, and leadership approaches were the main soft skills related to employability. These findings were consistent with Gallivan, Truex and Kvasny (2004), but additional findings also revealed self-motivation, organization and creativity as the skills mentioned in online job advertisement. MoHE, on the other hand, had identified seven elements of soft skills including communication, critical thinking and problem-solving, teamwork, lifelong learning and information literacy, entrepreneurship, professional ethics and morality, and leadership as the main aspects needed for graduates employability (Mohd Zaki, Mohd Salleh \& Wahid, 2008). Thus, findings from previous studies clearly showed that soft skills were important elements for ensuring employability, albeit different foci prevailed across countries and employers. Arguably, this is because different job specializations may require different types of skills and techniques.

An unemployment survey conducted in 2002 in Malaysia among graduates by the National Higher Education Research Institute (IPPTN) of Universiti Sains Malaysia suggested significant differences in graduate labour market outcomes across degrees (Morshidi, Rosni, Lim \& Mohammed Nasir, 2004). However, Chung and Yet (2009) indicated that having a suitable degree programme was not the only mechanism to guarantee good employment. This finding was consistent with research undertaken by Hanum, Razli and Azuddin (2008), who stated that in the current labor market there was a trend among most organizations which preferred to recruit those with experience, as the organisations no longer could provide in-house training due to shortage of allocation for training purposes.

Based on these previous research, we may conclude that having good qualifications is not enough to guarantee employability among graduates in Malaysia. In the competitive world nowadays, graduates 
not only need to be successful in academic achievements, but also need to possess the relevant skills in order to be employed by future employers. It should be noted here that employability is very much dependant on one having the right set of skills, and employment is thus, determined by job market vacancies.

\section{SIGNIFICANCE OF STUDY}

Numerous studies have been carried out to gauge the effectiveness of Finishing School programmes conducted by local higher learning institutions in improving their graduates' soft skills, especially in acquiring communication skills (Gurvinder \& Sharan, 2008; Khir, 2006; \& Chang, 2004). However, to our knowledge there is no research that has been undertaken to measure the effectiveness of Finishing School programmes in enhancing graduates employability. Hence, this research attempts to fill this gap. This research offered a variety of information, including the perception of the graduates towards the Finishing School programmes in enhancing their softskills, the perception of the employers with regards to local graduates and graduates from overseas, their expectations and the analysis on the marketability outcome.

Besides, information gathered from the employers through focus group discussions will enable us to determine which types of soft skills are mostly demanded by employers. This information will be useful for higher learning institutions as different types of job fields and organizations expect different types of skills from their prospective employees. Thus it is hoped that the findings from this research will enable higher learning institutions to develop their Finishing School programmes and tailored them to the market needs and thus help to enhance the employability of the graduates.

\section{METHODOLOGY}

\section{Measuring and Estimating the Effectiveness of Finishing School Programmes}

Measuring program effectiveness is important in order to show whether the outcomes of a particular program meets or exceeds the objectives. It may also help to determine if the program needs to be 
adjusted or changed, as well as to document the need for continued funding or program expansion (Chimezie, 1986). By assessing the effectiveness of the various programmes implemented, we will be able to identify the institutional best practices and used them as a model to be implemented by others. Therefore, an evaluation of Finishing School programmes is needed to point out the strengths and weaknesses of the programmes and the need for any changes in operation.

In order to measure the effectiveness of Finishing School programmes from the perspective of the students, a five point's Likert scale was used. Descriptive statistics (mean and standard deviation) were calculated to describe the characteristics of respondents. The hypothesis tests for two population means were used to test the perceived effectiveness of Finishing School programmes.

A Multinomial logit model was used to estimate the effectiveness of Finishing School programmes in terms of their effect on a graduate's marketability outcomes. The model was suitable since there were several graduate marketability outcomes such as i) employment commensurate with qualification, ii) employment does not commensurate with qualification, or iii) leaving the labour market for further studies.

A qualitative study was carried out to obtain information from employers with regards to their expectations and their perceptions of the soft skills possessed by graduates .

\section{Data Collection}

The primary data were collected by distributing questionnaires to one thousand two hundred $(1,200)$ fresh graduates in five selected local higher learning institutions which had run the Finishing School programmes. The participating universities were USM (Universiti Sains Malaysia), UniMAP (Universiti Malaysia Perlis), UUM (Universiti Utara Malaysia), UIAM (Universiti Islam Antarabangsa Malaysia) and UPM (Universiti Putra Malaysia). Due to the unavailability of a population frame, the data were collected using a convenient sampling design. The data were collected from August to October 2009. Participation of the respondents in the survey was on a voluntary basis. The questionnaires were developed with the main 
objective of obtaining graduate perceptions of the Finishing School programmes. The distributed questionnaires were constructed based on the Graduate Tracer Study formulated by MOHE. There were five major questions. The first and second questions solicited marketability outcome information; the third question sought Finishing School information and effectiveness as perceived by the graduates who have attended it; the fourth question solicited the same information but was targeted at those graduates who have not attended a Finishing School programme; the fifth question sought the graduates' opinions on the continuality of Finishing School programmes.

A different set of questionnaires were also distributed to 31 selected employers in various organizations around the Klang Valley, Ipoh and Penang which comprised private direct selling companies, consulting firms, manufacturers, banks, private higher education institutions, agro business firms, investment firms and telecommunication companies. All of these companies were public listed companies. As for the employers, the questionnaires basically focus on their perception towards the level of soft skills possessed by graduates and what were the important skills that they think were critical for graduates to have.

\section{RESULTS AND DISCUSSION}

\section{Students' Perception of Finishing School Programmes}

\section{Demographic Background of Respondents}

Table 1 presents the characteristics of respondents in terms of their higher learning institution, age and gender. The questionnaires were distributed to those who were selected by programme and by institution. In this study, only 1092 questionnaires were returned, which sufficiently represented the population of graduates in Malaysia, as suggested by Krejcie and Morgan (1970).

From Table 1, it is found that the majority of respondents were USM graduates (35.3 percent). This is perhaps due to the higher number of graduating students (5633 first degree graduates) in its $40^{\text {th }}$ convocation ceremony. Graduates from UniMAP only constituted 
2.6 percent of the total respondents, UUM 31.8 percent, UPM 18.3 percent, while another 12.1 percent of the respondents were graduates from UIAM.

As was to be expected from the selected group of graduates, most respondents were in the age range between $21-25$ years old (87.3 percent). This situation was due to the programme chosen, i.e., the first degree graduates. In Malaysia, almost all students enter higher learning institutions as early as 18 years old for diploma programmes and 19 years old for bachelor degree programmes.

Table 1

Characteristics of Respondents

\begin{tabular}{llcc}
\hline & & Frequency & $\%$ \\
\hline Higher Learning & USM & 385 & 35.3 \\
Institution & UniMAP & 28 & 2.6 \\
& UUM & 347 & 31.8 \\
& UIA & 132 & 12.1 \\
& UPM & 200 & 18.3 \\
Age & & \\
& 25 years old \& below & 935 & 87.3 \\
& 26-30 years old & 60 & 5.6 \\
& 30 - 35 years old & 23 & 2.2 \\
& 35 years old and above & 53 & 5 \\
Sex & & & \\
& Female & 704 & 64.6 \\
& Male & 388 & 35.4 \\
\hline
\end{tabular}

In terms of gender, more than half of the respondents in this study were female graduates (64.6 percent). This situation was consistent with the higher enrolment rate of female students in local higher learning institutions, as reported by Prof. Datuk Dr Morshidi Sirat, The Director General of Higher Education Department (The Star, 2013, July 12).

Respondents involved in this study came from various programmes offered. Table 2 shows that the highest number of respondents were from the Bachelor of Business Administration (Hons) programmes (17.7 percent), followed by Bachelor of Engineering (Hons) (17.4 percent), and Bachelor of Accounting (Hons) (11.9 percent). 
Table 2

Number of Respondents According to Types of Degree

\begin{tabular}{lcc}
\hline Types of degree & Frequency & $\%$ \\
\hline Bachelor of Business Administration (Hons) & 153 & 17.7 \\
Bachelor of Engineering (Materials) (Hons) & 150 & 17.4 \\
Bachelor of Accounting (Hons) & 103 & 11.9 \\
Bachelor of Applied Science & 75 & 8.7 \\
Bachelor of Arts & 65 & 7.5 \\
Bachelor of Computer Science (Hons) & 58 & 6.7 \\
Bachelor of Administration & 41 & 4.8 \\
Bachelor of Human Sciences (Hons) & 39 & 4.5 \\
Bachelor of Islamic Revealed Knowledge \&Heritage & 27 & 3.1 \\
Bachelor of Economics (Hons) & 26 & 3.0 \\
Bachelor of Housing & 21 & 2.4 \\
Bachelor Of Finance (Hons) & 18 & 2.1 \\
Bachelor of Health Science & 18 & 2.1 \\
Bachelor of Communication (Hons) & 16 & 1.9 \\
Bachelor of Pharmacy & 11 & 1.3 \\
Bachelor of Fine Arts & 10 & 1.2 \\
Bachelor of Hospitality Management (Hons) & 9 & 1.0 \\
Bachelor of Laws (Hons) & 5 & 0.6 \\
Bachelor of Architecture (Hons) & 5 & 0.6 \\
Bachelor of Human Resource Management (Hons) & 5 & 0.6 \\
Bachelor of Quantity Surveying (Hons) & 2 & 0.5 \\
Bachelor of Music & 0.1 \\
Bachelor of International Affairs Management (Hons) & 1 & \\
\hline & 5 & \\
\hline
\end{tabular}

\section{Characteristics of Respondents}

The analysis of the 1092 returned questionnaires showed that only 273 of the respondents (25 percent) had attended Finishing School programmes during their studies. From this number, UPM graduates represented the highest number of participants ( 94 percent). Although USM's graduates represent the larger proportion of respondents, only 7.3 percent had attended the programme (Table 3 ). 
Table 3

Number of Respondents in Finishing School by University

\begin{tabular}{lcr}
\hline & $\begin{array}{c}\text { Frequency } \\
(\mathrm{n}=273)\end{array}$ & $\%$ \\
\hline USM & 28 & 7.3 \\
UniMAP & 1 & 3.7 \\
UUM & 49 & 14.1 \\
UIAM & 7 & 5.3 \\
UPM & 188 & 94.0 \\
\hline
\end{tabular}

According to the information gathered from the questionnaires, there were nine types of popular Finishing School programmes. Table 4 indicates that the most popular Finishing School programme is on resume writing, followed by job interviews, interpersonal communication skills, job finding, leadership, teamwork, protocol and etiquette, thinking skills, and ICT skills.

Table 4

Types of Finishing School Programmes Attended by Respondents

\begin{tabular}{lcc}
\hline Type of Finishing School Programmes & Frequency & $\%$ \\
\hline Resume Writing & 245 & 11.3 \\
Job Interview & 243 & 11.2 \\
Interpersonal Communication Skills & 240 & 11.1 \\
Job Finding & 222 & 10.3 \\
Leadership Skills & 211 & 9.75 \\
Teamwork Skills & 205 & 9.47 \\
Protocol \& Etiquette & 200 & 9.24 \\
Thinking Skills & 144 & 6.7 \\
System and Technology Skills & 124 & 5.3 \\
\hline
\end{tabular}

The findings in Table 5 show that 50.6 percent of respondents attended a Finishing School programme on a compulsory basis. Fifty five percent of respondents agreed that they attended the course as they had been selected, and 84.7 percent of respondents stated that they attended the programme voluntarily. From the 273 respondents who attended Finishing School, only 28.2 percent of the respondents pointed out that they had to pay fees to attend the programmes. 
Table 5

Attendance of the Finishing School Programmes by Reason

\begin{tabular}{lcc}
\hline Reasons & Frequency & $\%$ \\
\hline Compulsory to Attend Finishing School & 43 & 50.6 \\
Being Selected to Attend Finishing School & 47 & 55.3 \\
Attend Finishing School Voluntarily & 72 & 84.7 \\
\hline
\end{tabular}

Note: The percentage is based on the 273 respondents who attended Finishing School programmes.

\section{Effectiveness of the Finishing School Programme}

The majority of respondents agreed that they were satisfied with the possession of all listed skills after they had attended a Finishing School programme, with a mean of 4.16. This indicates that from the perception of the graduates, the Finishing School programmes were successful in improving their soft skills. Proficiency in English was the most obvious improvement, where the mean increases from 3.10 to 3.93 (Table 6). However, it is still the lowest among all the skills.

Table 6

Skills Before and After Attending Finishing School Programmes

\begin{tabular}{lcccc}
\hline \multirow{1}{*}{ Skills } & \multicolumn{2}{c}{ Before attendance } & \multicolumn{2}{c}{ After attendance } \\
\cline { 2 - 5 } & Mean & $\begin{array}{c}\text { Std } \\
\text { Deviation }\end{array}$ & Mean & $\begin{array}{c}\text { Std } \\
\text { Deviation }\end{array}$ \\
\hline Interpersonal communication skills & 3.29 & 0.80 & 4.09 & 0.63 \\
Creative and critical thinking skills & 3.44 & 0.74 & 4.13 & 0.60 \\
Problem solving skills & 3.41 & 0.76 & 4.16 & 0.57 \\
Analytical skills & 3.36 & 0.74 & 4.10 & 0.60 \\
Proficiency in English & 3.10 & 0.55 & 3.93 & 0.96 \\
Team work & 3.51 & 0.72 & 4.27 & 0.65 \\
Inculcation and practicing of & 3.55 & 0.76 & 4.26 & 0.66 \\
positive values & & & & \\
Exposure to general Knowledge & 3.40 & 0.75 & 4.16 & 0.70 \\
and current issues & 3.14 & 0.82 & 4.22 & 0.61 \\
Job interview skills & & \multicolumn{3}{c}{ (continued) }
\end{tabular}




\begin{tabular}{lcccc}
\hline \multicolumn{1}{c}{ Skills } & \multicolumn{2}{c}{ Before attendance } & \multicolumn{2}{c}{ After attendance } \\
\cline { 2 - 5 } & Mean & $\begin{array}{c}\text { Std } \\
\text { Deviation }\end{array}$ & Mean & $\begin{array}{c}\text { Std } \\
\text { Deviation }\end{array}$ \\
\hline $\begin{array}{l}\text { Resume and job application } \\
\text { letter writing }\end{array}$ & 3.26 & 0.86 & 4.24 & 0.61 \\
Job search & 3.16 & 0.81 & 4.22 & 0.62 \\
Demonstrate good image & 3.48 & 0.76 & 4.29 & 0.60 \\
Demonstrate self-confidence & 3.45 & 0.73 & 4.21 & 0.66 \\
ICT skills & 3.45 & 0.73 & 4.16 & 0.64 \\
Leadership skills & 3.34 & 0.78 & 4.16 & 0.72 \\
\hline Overall & 3.37 & 0.58 & 4.16 & 0.48 \\
\hline
\end{tabular}

Hence, referring to Table 6, the value of the means for all soft skills after attending the Finishing School programme were greater than before attending the Finishing School programme. Interestingly, the value of the means for soft skills after attending the Finishing School programme points out that the graduates' answer tend to show no significant difference. In other words, the majority of the graduates agreed that they were satisfied with their soft skills after attending the Finishing School programme.

Overall, the mean for perception of the respondents on their skills after attending Finishing School (4.16) is greater than skills before attending Finishing School (3.37). This mean difference is found to be significant with p-value of almost zero (paired sample t-test). We can conclude that there is a significant difference between skills possessed by respondents before and after attending Finishing School programmes.

Moreover, Table 7 shows that from the perspective of the respondents on the effectiveness of 'Finishing School', measured on a five point rating scale ( 1 being 'not effective at all' to 5 being 'very effective'), it was found that the mean of respondents attending the Finishing School programme (4.06) is greater than the mean of respondents not attending the Finishing School programme (3.59).

To summarize, the majority of the respondents who attended the Finishing School programme were satisfied with the programme and perceived that the programme improved their soft skills and was effective in improving graduates' employability. However, 
the mean of respondents who did not attend a Finishing School programme indicates that respondents were not sure whether the course really improved graduates' employability or not. This is sensible as they did not experience it, and therefore they were not able to determine whether the programme has improved their soft skills to make them more employable in the job market. In addition, from the 1092 respondents in this study, almost all respondents (96 percent) recommended that the Finishing School programme should be continued.

Table 7

Perception of respondents on effectiveness of 'Finishing School'

\begin{tabular}{lcc}
\hline & Mean & Std deviation \\
\hline Those who attended FS & 4.06 & 0.70 \\
Those who did not attend FS & 3.59 & 0.76 \\
\hline
\end{tabular}

\section{The Effectiveness of Finishing School in Enhancing Graduate Marketability Outcomes}

Besides using self-perception in measuring the effectiveness of the Finishing School programmes, the study provides an estimation of the effectiveness of Finishing School programmes by focusing on the probability of obtaining employment that commensurate with qualification among graduates. In the estimated multinomial logit model, an odds ratio greater than one indicates the positive effect of the Finishing School programme on employment status and an odds ratio less than one indicates the negative effect of the Finishing School programme on employment status. Table 8 shows that age has a positive impact on the probability to obtain a job which commensurates with one's qualification. It means that the older the graduates, the higher the probability of being employed in jobs that commensurate with their qualifications. This effect is significant at a 1 percent level.

The dummy variable for Finishing School programme in the Multinomial logit model is built with those who did not attend a Finishing School programme as the comparison group. Hence, the odds ratio of 0.0206 means that those who did not attend the programme had a higher probability of being employed in jobs that commensurate with their qualifications than those who attended the 
programme. This situation may be due to the academic performance of graduates. As mentioned earlier, many of the Finishing School programmes organized by public local institutions are catered for and made compulsory for final year students with a CGPA less than 3.0.

Table 8

Multinomial Logit Model

\begin{tabular}{lcccc}
\hline \multicolumn{1}{c}{ Ind. Variables } & FT1: (UNE) & \multicolumn{2}{c}{ FT2: (UNE) } \\
\hline & Odds ratio & P-value & Odds ratio & P-value \\
\hline Age & 3.3129 & 0.0000 & 2.7100 & 0.0001 \\
Male & 0.9916 & 0.9747 & 1.6150 & 0.0275 \\
FS & 0.0393 & 0.0032 & 0.0206 & 0.0003 \\
Effectiveness of FS & 0.9096 & 0.5571 & 0.8565 & 0.2607 \\
Continuity of FS & 0.2924 & 0.0328 & 0.4967 & 0.1899 \\
USM & 6.9812 & 0.0766 & 4.9875 & 0.0061 \\
UUM & 6.1963 & 0.0987 & 2.7828 & 0.0868 \\
UIA & 14.6689 & 0.0167 & 4.1973 & 0.0234 \\
\hline
\end{tabular}

The Finishing School programme in certain institutions was meant for those with a low CGPA as the intention is to give them the added value skills for employability. However, this is not sufficient to ensure that they obtain employment that commensurate with their qualification. Nevertheless attending Finishing School gives them the perception that they have improved their soft skills.

\section{Employers' Perception and Expectation of Graduate Employability}

\section{Skills of Graduates Sought After by Employers}

Based on a survey conducted among 31 companies representing various industries and sectors in Malaysia, it was found that most of them stated that their organizations require candidates who possess both technical and soft skills. All respondents suggested a list of essential skills that a candidate had to have before he or she was hired for a particular post. As shown in Table 9, the three most important soft skills required by employers were critical and problem solving skills (31), lifelong learning and information management (26), and English communication (25). 
Table 9

Types of Skills Required by Employers

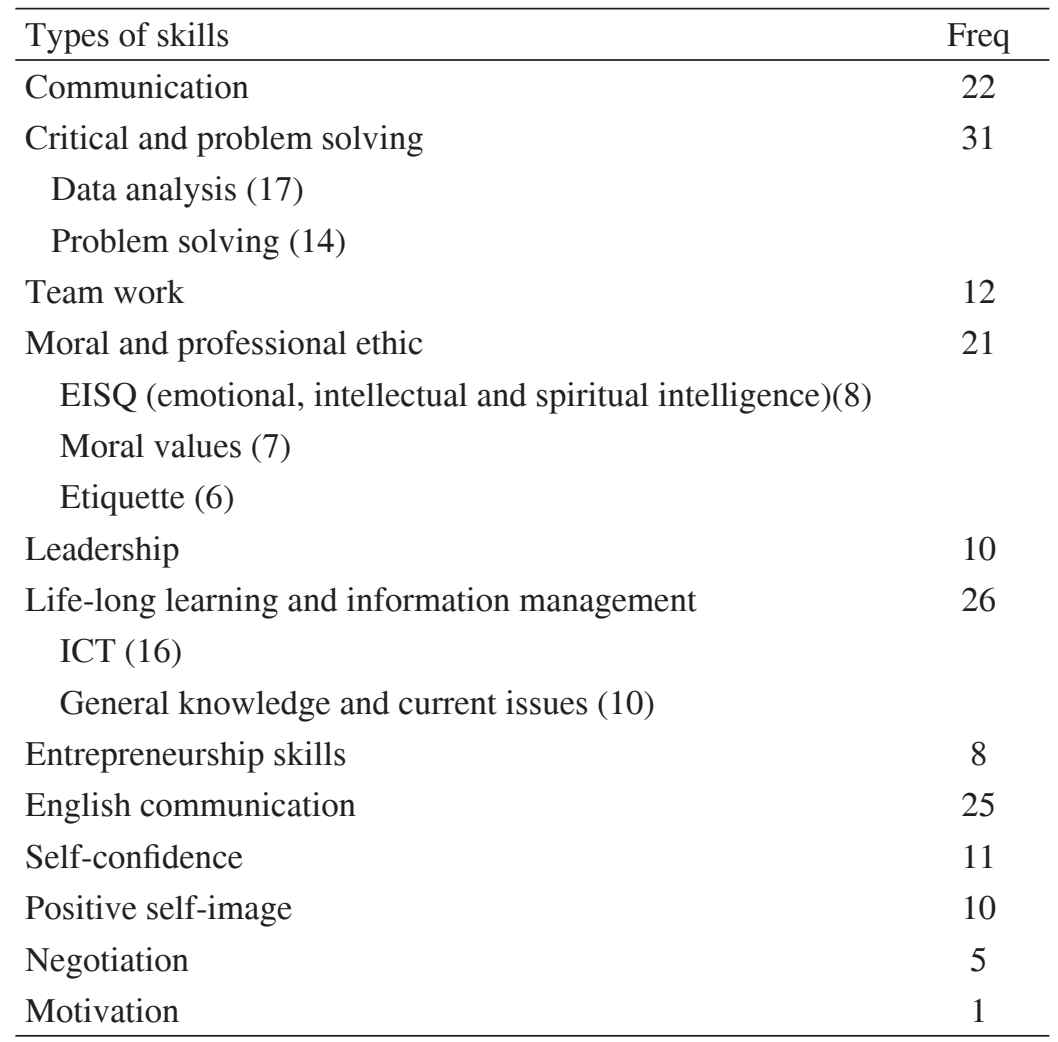

Note: Total frequency (company) $=31$; the values in parenthesis are the frequencies of sub-soft skills. They are added and the total is showed in the frequency column.

Strengths and Weaknesses of Graduates of Local Public Higher Education Institutions: The Employers' Perspectives

Based on the qualitative data collected from both the interview and open ended questionnaires, the various company representatives stated that graduates from local universities had a number of personal strengths and weaknesses. The details mentioned by them are as shown in Table 10. According to the respondents, there were two main strengths that the local graduates had: First, were receptive to instructions given, and second, had respect for others (both are 16.13 percent). Meanwhile, their significant weaknesses were general communication skills (38.71 percent), English communication skills 
(25.81 percent), lack of confidence (16.13 percent), lack of critical and creative thinking skills (12.91 percent), and being afraid to ask questions and avoiding making mistakes (9.68 percent).

\section{Table 10}

Strengths and Weaknesses of Graduates from Employers' Perspective

\begin{tabular}{|c|c|c|c|c|c|}
\hline Strengths & Freq & $\%$ & Weaknesses & Freq & $\%$ \\
\hline $\begin{array}{l}\text { Able to complete } \\
\text { report within a stipulated } \\
\text { time }\end{array}$ & 1 & 3.23 & Communication skills & 12 & 38.71 \\
\hline Easily accepting guidance & 5 & 16.13 & Problem solving skills & 2 & 6.46 \\
\hline $\begin{array}{l}\text { Prone to learn latest } \\
\text { technology }\end{array}$ & 3 & 9.68 & $\begin{array}{l}\text { Expect working environment to } \\
\text { be faultless }\end{array}$ & 1 & 3.23 \\
\hline $\begin{array}{l}\text { Honest, trustworthy and } \\
\text { ethical }\end{array}$ & 4 & 12.90 & $\begin{array}{l}\text { Overly confident with own } \\
\text { existing skills }\end{array}$ & 1 & 3.23 \\
\hline Young and enthusiastic & 2 & 6.46 & $\begin{array}{l}\text { Prone to misunderstand } \\
\text { instructions given }\end{array}$ & 2 & 6.46 \\
\hline \multirow[t]{13}{*}{ Respect for others } & 5 & 16.13 & Quick to draw conclusions & 1 & 3.23 \\
\hline & & & Impatient & 2 & 6.46 \\
\hline & & & Lack of leadership skills & 1 & 3.23 \\
\hline & & & Unable to utilize prior experience & 1 & 3.23 \\
\hline & & & $\begin{array}{l}\text { Too focused on personal } \\
\text { career and neglecting } \\
\text { social and spiritual aspects }\end{array}$ & 1 & 3.23 \\
\hline & & & Lack of confidence & 5 & 16.13 \\
\hline & & & Unable to put up with pressure & 3 & 9.68 \\
\hline & & & Poor communication in English & 8 & 25.81 \\
\hline & & & $\begin{array}{l}\text { Lack of critical and creative } \\
\text { thinking skills }\end{array}$ & 4 & 12.91 \\
\hline & & & $\begin{array}{l}\text { Unable to apply theory that they } \\
\text { had learned in the real world } \\
\text { business }\end{array}$ & 1 & 3.23 \\
\hline & & & Not proactive & 2 & 6.46 \\
\hline & & & Dislike job change & 2 & 6.46 \\
\hline & & & $\begin{array}{l}\text { Afraid to pose questions and try } \\
\text { to avoid making mistakes while } \\
\text { working }\end{array}$ & 3 & 9.68 \\
\hline
\end{tabular}




\section{Comparison between Local and Overseas Graduate Candidates}

From the perspective of the employers, overseas graduates tended to have more and better competitive advantages as compared to the local graduates. Their strengths could turn into essential added values that helped them to take part in the labour market faster and easier. Thus, by possessing more personal competitive advantages, overseas graduates could become a better candidate for various posts and jobs that were on offer by employers from different industries and sectors in Malaysia. For comparison, potential employers were more than willing to pay higher salary or wages to them compared to the local graduates. Table 11 shows the ranking of strengths that overseas graduate candidates had as perceived by the employers.

Table 11

Strength of Overseas Graduate

Strengths

Able to communicate and speak fluently in English Rank

Have better strengths and courage to face challenges 1

Have higher self-confidence and are more independent than

local graduates

A better problem solver, more mature and have a more holistic view

Generate more comprehensive ideas and aware of current issues 5

Note: The information as solicited from 31 employers without specific regard to which foreign universities the graduates graduated from.

\section{Proposed Soft Skills by Employers}

Apart from soliciting information with regard to the level of soft skills possessed by the current graduates, the employers were also asked about the specific skills which were deemed important while hiring. The feedback from the employers show that among the three most important soft skills suggested by them were communication skills (including English), critical, creative thinking and problem solving and application of theory to the real business world. The employers also perceived overseas graduates as possessing more strengths and skills that could push them to advance faster in their 
careers. Consequently, some of the employers were willing to pay higher wages to overseas graduates for a similar type or scope of job offered to local graduates.

\section{CONCLUSION}

Numerous studies have shown that deficiency in soft skills among graduates in Malaysia is one of the main determinants of graduate unemployment. In the competitive graduate labour market nowadays, employers require fresh graduate to possess both the required technical and soft skills. This is important since most of the employers consider these soft skills as significant to make their companies remain competitive in the era of globalization. The government and local higher learning institutions are concerned about the employability issue and so have introduced the Finishing School programme mainly to enhance the employability rate of graduates in Malaysia. Various modules and programmes have been developed by local higher learning institutions to equip their students with a variety of skills demanded by most industries.

Based on the perception of the graduates, the mean for overall skills after attending the Finishing School programme had increased, thus reflecting that the majority of graduates were satisfied with the soft skills that they had acquired. This is supported by the result of the t-test from the regression analysis, where the critical value indicates there is a significant difference between the possession of skills before and after attending the Finishing School programme. This finding is consistent with previous studies done by Abdul Rahim, Ariza, Mohd Noor and Azizah (2007) where students were more confident with their soft skills ability after attending the Finishing School programme. This study has also shown that majority of the respondents who attended Finishing School programme agreed that the course was effective in improving graduate employability as the programme had helped respondents to improve their soft skills.

Measuring the effectiveness of Finishing School programme by comparing the employment status among those who attended and did not attend Finishing School programme however, has shown that this programme is not effective in enhancing graduates' employability. The result of the estimated Multinomial Logit model 
shows that graduates who attended the 'Finishing School' had lower probability of obtaining full time employment that commensurate with their qualification compared to graduates who did not attend the programmes. Reasons for this phenomenon might be due to the lack of experience and lower CGPA obtained by the respondents who attended the Finishing School programmes.

Age, on the other hand, has a positive impact on employment status. It means that as age increases, the higher the probability for them to be employed. This can be explained as the older respondents in this research may have been working for several years before they further their study in local higher learning institutions. This finding is consistent with Lim, Rich and Haris (2008) and Hanum, Razli and Azuddin (2008), who shows that in the current labour market, there is a trend that most organizations prefer to recruit those with working experience as they no longer provide in-house training.

Based on the findings from the companies interviewed, soft skills in communication (including English), critical and creative thinking, problem solving and the ability to apply theories to the real world business are the main skills looked for by employers and are important for future graduates. As far as the Finishing School programmes at local higher learning institutions are concerned, most of the soft skills required by employers have been emphasized and embedded in the module. Thus, it is suggested that for the Finishing School programmes to contribute effectively to graduate employability, methods of implementation and, the timing and length of the programmes should be revised. This is important to ensure that students are interested to join the programmes and the impact from the programmes is immensely felt.

\section{REFERENCES}

Abd. Rahim, R., Ariza, I., Mohd Noor, C. A. R. \& Azizah, E. (2007, Dec). Program ketrampilan graduan untuk pelajar Universiti Darul Iman Malaysia tahun 2007. Paper presented at Persidangan Pengajaran dan Pembelajaran peringkat Pengajian Tinggi, Sri Kembangan, Selangor, Malaysia.

Brown, P., \& Hesketh, A. (2004). The mismanagement and talent: Employability and jobs in the knowledge economy. London: Macmillan. 
Chang, M. (2004, July). Why some graduates are more marketable than others: Employers'perspective. Paper presented in a Workshop on Enhancing Graduate Employability in a Globalised Economy, Economic Planning Unit, Malaysia.

Chimezie, A. B. (1986). An evaluation model of training outcomes for higher education. Education Evaluation Policy, 8 (2), 167-178.

Chung, K. Y., \& Yet, M. E. (2009). Perception Differential between Employers and Undergraduates on the Importance of Employability Skills. International Education Studies, 2(1), 95-105.

Feng, M. (2008, March). Assessing the introduction of e-learning on college students: An NCUT Case Study. Paper Presented at the International Joint Conference on e-Commerce, e-Administration, e-Society and e-Education, Bangkok, Thailand.

Gallivan, M., Truex, D., \& Kvasny, L. (2004). An analysis of the changing demand patterns for information techmology professionals. The Data BASE for Advances in Information Systems, 35 (1), 64-87.

Gurvinder, K. G. S., \& Sharan, K. G. S. (2008). Malaysian graduates' employability skills. E-journal of UNITAR, 4(1), 15-45.

Hanum, H., Razli, A. \& Azuddin, B. (2008, Oct). Persepsi pelajar terhadap penerapan kemahiran insaniah dalam program Baktisiswa Perdana UniMAP. Paper presented at the NASDEC Conference, UTM, Malaysia.

Hillage, J. (1998). Employability: developing a framework for policy analysis. Research Report R85, Department for Education and Employment, Malaysia.

Lim, H. E., Rich, J. \& Haris, M. N. (2008). Employment outcomes of graduates: The case of Universiti Utara Malaysia. Asian Economic Journal, 22(3), 321-341.

Khir, K. (2006, July). Training employable graduates: Innovation in training methodology. Paper presented at National Conference on Challenges in Technical Education and Training; Enhancing Employability among Graduates. Batu Pahat, Johor, Malaysia.

Krejcie, R. V. \& Morgan, D. W. (1970). Determining sample size for research activities. Educational and Psychological Measurement, 30, 607-610. 
Manishankar, C. (2009). Impact of soft skills in the professional domain. India: The Icfai University Press.

Mason, G., William, G., \& Crammer, S. (2006). Employability skills initiative in higher education: What effects do they have on graduates' labor market outcomes? Retrieved from http://niesr.ac.uk

Mlatsheni, C. (2005). The youth labor market: What does it takes to succed? Journal of Economic, 76(1), 450-496.

Mohd Zaki, K. Mohd Salleh, B., \& Wahid, R. (2008, August). Laporan kajian soal selidik penerapan kemahiran insaniah di kalangan pelajar dalam aktiviti pengajaran dan pembelajaran di institusi pengajian tinggi. Paper presented to Seminar Kemahiran Insaniah dan Kesejahteraan Sosial, Melaka, Malaysia.

Morshidi, S., Rosni, B., Lim, H. E., \& Mohammed Nasir, K. (2004). Pencapaian akademik dan kebolehgunaan tenaga siswazah institusi pengajian tinggi. Malaysia: IPPTN.

Morshidi, S. (2013, July 12). More women accepted into public varsities. The Star. Retrieved from http://www.thestar.com.my Morshidi, S., Abd. Aziz, B., Munir, S., Abd Majid, M. I., Rosni, B., et al. (2004). Masalah pengangguran di kalangan siswazah. Malaysia: IPPTN.

Shamsuddin, B. (2009, July). Governance and government: Employer perspective of graduates employability. Paper presented at the Employer Federation Conference, Putrajaya, Malaysia.

Skimming, C. M. (2007). An investigation to identify the key strategies Carnold College can use to improve employability of its students. Journal of Management, 11(7), 1-26.

Tracker, R. A., \& Yost, C. A. (2002). Training students to become effective workplace team. Journal of Team Performance Management, 8(3), 89-94.

Umar, I. R. \& Ahmad, N. H. (2010). Trainee teachers' critical thinking in an online discusion forum: A content analysis. Malaysian Journal of Learning and Instruction, 74(7), 75-91. 